\title{
PEMIKIRAN AFZALUR RAHMAN TENTANG KONSUMSI DALAM EKONOMI ISLAM
}

\author{
M. Jatmika \\ (Staf BRI Dumai)
}

\begin{abstract}
Abstrak
Tujuan penelitian ini untuk mengetahui pemikiran Afzalur Rahman tentang konsumsi dalam ekonomi Islam. Metode penelitian yang penulis gunakan adalah studi kepustakaan (Library Research), dan sebagai data primer dalam penulisan ini adalah literatur karangan Afzalur Rahaman tentang konsumsi yaitu dalam buku Muhammad Sebagai Seorang Pedagang, dan Doktrin Ekonomi Islam. Metode pengumpulan data yang penulis gunakan dalam penelitian ini adalah deskriptif analitik, deduktif, dan komperatif. Setelah penulis menelaah pemikiran Afzalur Rahman tentang konsumsi, penulis melihat bahwa konsumsi dalam ekonomi Islam harus memperhatikan kepada hal-hal kualitas dan kemurnian, standar kehidupan, dan kehidupan sederhana. Dengan prinsip keadilan untuk menentukan cara penggunaan harta, umat Islam diperintahkan supaya terhindar dari sifat bakhil dan harus dapat memelihara dirinya dari bahaya pemborosan harta kekayaan, oleh karena itu mengambil jalan pertengahan diantara kedua jalan ekstrim yaitu antara kebakhilan dan pemborosan harta. Pada satu sisi Al-Qur'an melarang pengeluaran pembelanjaan yang melampaui batas, terutama dalam melampiaskan keinginan pribadi, sementara disisi lain Islam juga mencela orang yang berpantang dari segala kenikmatan yang baik dan suci. Orang-orang yang berpantang diri terhadap kesenangan duniawi diperintahkan untuk mengubah sikap mereka terhadap kehidupan.

Kata Kunci: Pemikiran Afzalur Rahman, Konsumsi, Ekonomi Islam
\end{abstract}




\section{A. Pendahuluan}

1. Latar Belakang

Didalam kehidupan dan kehidupannya, orang memiliki banyak sekali kebutuhan, keinginan dan keperluan yang kesemuanya itu menghendaki pemenuhan. Mereka membutuhkan makan, pakaian, ilmu, pelayanan, kehormatan, dan sekian juga kebutuhan lagi. Secara garis besar, maka kebutuhan manusia itu dikelompokkan kedalam dua kelompok besar, yaitu kebutuhan fisik atau kebutuhan badaniah, dan kebutuhan psikis atau kebutuhan kejiwaan. ${ }^{1}$

Ingin kenyang, ingin punya motor, ingin sehat, adalah contoh-contoh untuk kebutuhan badaniah atau kebutuhan fisik, sedangkan ingin terhormat, ingin punya anak, ingin rumah tangga bahagia, adalah contoh-contoh untuk kebutuhan psikis atau kebutuhan kejiwaan.

Semua kebutuhan itu membutuhkan pemenuhan, dan pemenuhannya itu tidak lain barang dan jasa. Kebutuhan manusia itu luar biasa banyaknya, baik kebutuhan fisik maupun kebutuhan psikis, baik keinginan yang baik maupun keinginan yang jahat. Sedemikian banyaknya, sehingga para ahli ekonomi mengatakan bahwa kebutuhan manusia itu tiada terbatas. Seseorang bisa saja dengan mudah mencapai batas keinginan makan bila ia sudah kenyang. Jadi sebenarnya kebutuhan manusia itu ada pula batasannya. Hanya saja untuk sebahagian besar penduduk setiap negara, bahkan penduduk dunia sebagai suatu keseluruhan, keinginan dan kebutuhan itu adalah sedemikian banyaknya, sehingga jauh melampaui jumlah barang dan jasa yang dengan keduanya itulah keinginan dan kebutuhan mereka terpenuhi.

${ }^{1}$ Suherman Rasyidi, Pengantar Teori Ekonomi Pendekatan Kepada Teori Ekonomi Mikro dan Makro, (Jakarta: PT Raja Grafindo Persada, 2000), h. 50. 
Ilmu ekonomi bertugas untuk mempertemukan kedua yang saling bertentangan, yaitu antara keinginan dan kebutuhan manusia yang tiada batas dengan barang dan jasa yang langka untuk memenuhi kebutuhan tersebut.

Adapun kebutuhan manusia itu, bertingkat-tingkat adanya. Pada tingkat pertama primary needs atau kepatuhan primer, orang yang membutuhkan sandang (pakaian), pangan (makanan dan minuman), dan papan (tempat tinggal). Kalau kebutuhan primer ini sudah tercapai, maka muncullah di dalam pikiran manusia untuk memenuhi secondary needs atau kebutuhan tingkat keduanya, yang antara lain berisi kebutuhan akan sepatu, sepeda, pendidikan, dan lain sebagainya. Demikian adanya, sehingga terdapat kebutuhan tingkat ketiga (tertiary needs), kebutuhan tingkat keempat (quartiary needs) dan seterusnya. Orang akan sampai pada suatu tingkat kebutuhan tertentu hanya sesudah tingkat kebutuhan sebelumnya terlampaui. $^{2}$

Pada anggaran (asumsi) bahwa kepuasan yang diperoleh konsumen dalam mengkonsumsi barang dapat diukur dengan angka (rupiah, misalnya), dan banyak disukai dari sedikit (more priter to less). Makin tinggi kepuasan yang diperoleh ditunjuk dengan angka yang lebih besar. Uraian berikut akan menjelaskan hubungan antara kepuasan yang diperoleh dengan keputusan tentang beberapa jumlah yang dibeli.

Kepuasan (utility) yang diperoleh dari mengkonsumsi suatu barang akan mempengaruhi keputusan tentang beberapa banyak yang akan dibeli. Ada dua konsep kepuasan, pertama kepuasan total (total utility) yang diperoleh oleh konsumen dari mengkonsumsi jumlah barang tertentu, dan kedua kepuasan marjinal (marginal utility) adalah tambahan kepuasan yang

\footnotetext{
${ }^{2}$ Suherman Rasyidi, ibid., h. 51.
} 
diperoleh karena konsumen menambah satu unit barang yang dikonsumsikan. $^{3}$

Apabila seseorang menerima pendapatannya dari hasil bekerja, maka ia pun akan segera merencanakan untuk membelanjakan pendapatannya itu, setelah dikurangi dengan segala kewajiban (seperti pajak, dan sebagainya). Jadi pendapatannya itu mestilah dikeluarkan atau di belanjakan. Tidak ada seseorang yang normalpun di dunia ini yang akan menerus menyimpan pendapatannya. Dalam pada itu, setiap pendapatan niscayalah akan pertamatama dikeluarkan untuk keperluan konsumsi, sedangkan sisanya, kalau masih ada bersisa, akan ditabung. ${ }^{4}$

Salah satu sendi utama ekonomi Islam ialah sifatnya yang pertengahan (keseimbangan). Bahkan ciri ini merupakan jiwanya. Jiwa bagi disiplin juga berfungsi sebagai peraturan untuk membedakan satu disiplin dengan disiplin lainnya. Misalnya disiplin Islam berbeda dengan disiplin sosialisme dan kapitalisme.

Jiwa peraturan kapitalisme terlihat jelas pada egoisme baik didalam menumpuk harta kekayaan, mengembangkan maupun membelanjakannya. ${ }^{5}$ Sistem kapitalis memberikan fasilitas kepada individu sehingga menjadi besar dan bertindak sewenang-wenang tanpa mementingkan kemaslahatan masyarakat yang tertumpu kepada negara. ${ }^{6}$

Afzalur Rahman mengemukakan Al-Qur'an telah mengambil jalan tengah diantara dua cara hidup yang ekstrim, yaitu paham materialisme dan asketisme. Pada satu sisi Al-Qur'an melarang pengeluaran pembelanjaan

3 Nopirin, Ph D, Pengantar Ilmu Ekonomi Makro dan Mikro, (Yogyakarta: BPFE, 1994), h. 288.

${ }^{4}$ Paula Samuelson dan Wiliam D Nord Haus, Ekonomi, (Jakarta: Erlangga), h. 121.

5 Yusuf Al-Qardhawi, Norma dan Etika Ekonomi Islam, (Jakarta: Gema Insani Press, 1997), Cet. Ke-2, h. 69.

${ }^{6}$ Yusuf Al-Qardhawi, ibid., h. 71. 
yang melampaui batas, terutama dalam melampiaskan keinginan pribadi, sementara disisi lain Islam juga mencela orang yang berpantang dari segala kenikmatan yang baik dan suci. Orang-orang yang berpantang diri terhadap kesenangan duniawi diperintahkan untuk mengubah sikap mereka terhadap kehidupan. ${ }^{7}$

Dalam masalah gradasi standar ekonomi, Islam mempertahankan persamaan serta menerima prinsip hak untuk memperoleh nafkah hidup dari setiap warga negara. Islam menegaskan bahwa tidak seorangpun dihilangkan kebutuhan dasar hidupnya dan bahwa tidak seorangpun menghambur-hamburkan kekayaannya dalam kemewahan. Islam menganggap sebagai tanggung jawab negara untuk membagikan kebutuhankebutuhan pokok kepada warga negaranya serta untuk menjaga perbedaan dalam gradasi-gradasi ekonomi dalam batas-batas kesederhanaan dan kewajaran, supaya kejahatan dari paham kapitalisme (yaitu berlebih-lebihan dalam kemewahan) dan paham komunisme (yaitu cara hidup dan pemerataan yang tidak wajar dan palsu) tidak terjadi di dalam komunitas muslim. Dengan ini kejahatan ekonomi yaitu sikap hidup yang berlebihlebihan dan kekikiran dalam konsumsi, dengan sendirinya hilang dari sebuah masyarakat muslim. ${ }^{8}$

Konsumsi berlebih-lebihan, yang merupakan ciri khas masyarakat yang tidak mengenal Tuhan, dikutuk dalam Islam dan disebut dengan istilah israf (pemborosan) atau tabzir (menghambur-hamburkan uang/harta tanpa guna). Menurut Islam, anugerah-anugerah Allah itu milik semua manusia dan suasana yang menyebabkan sebagian di antara anugerah-anugerah itu berada di tangan orang-orang tertentu tidak berarti bahwa mereka dapat memanfaatkan anugerah-anugerah itu untuk mereka sendiri, sedangkan

7 Afzalurrahman, Muhammad Sebagai Seorang pedagang, (Jakarta: Yayasan Swarna Bhumy, 1997), Cet. Ke-2, h. 191.

${ }^{8}$ Afzalurrahman, ibid., h. 191. 
orang lain tidak memiliki bagiannya sehingga banyak diantara anugerahanugerah yang diberikan Allah kepada umat manusia itu masih berhak mereka miliki walaupun mereka tidak memperolehnya. Dalam Al-Qur'an Allah SWT mengutuk dan membatalkan argumen yang dikemukakan oleh orang kaya yang kikir karena ketidaksediaan mereka memberikan bagian atau miliknya ini.

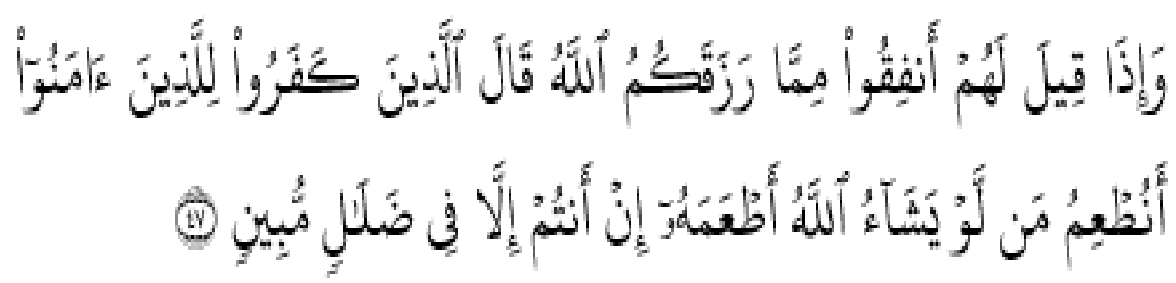

Artinya: "Bila dikatakan kepada mereka, "Belanjakanlah sebagian rizki Allah yang diberikan-Nya kepadamu”, orang-orang kafir itu berkata kepada orang-orang yang beriman, "Apakah kami harus memberi makan orang-orang yang jika Allah menghendaki akan diberi-Nya makan? Tiadalah kamu melainkan dalam kesesatan yang nyata" (Yasiin: 47).9

Abdul Mannan mengemukakan bahwa perintah Islam dalam menetukan konsumsi ditentukan dengan berbagai prinsip yaitu prinsip keadilan, prinsip kebersihan, prinsip kesederhanaan, prinsip kemurahan hati, dan prinsip moralitas. ${ }^{10}$

Afzalur Rahman adalah seorang cendikiawan muslim ahli ekonomi yang terkemuka di dunia. Ia berasal dari Pakistan, dan menjabat sebagai Deputy Sekretary General dari Muslim School Trust London. Selain sebagai praktisi ekonomi yang handal, mempunyai corak pemikiran yang modern. Dalam karyanya, Doktrin Ekonomi Islam, Muhammad sebagai Seorang Pemimpin Militer, dan Muhammad sebagai Seorang Pedagang, dengan ini

${ }^{9}$ Departemen Agama R I, Al-Qur'an dan Terjemahan, (Semarang: CV. Toha Putra, 1989), h. 96.

${ }^{10}$ M Abdul Mannan, Ekonomi Islam Teori dan Praktek, (Yogyakarta: Dana Bakti Wakaf, 1997), h. 79. 
Afzalur Rahman lebih menonjolkan sosok nabi Muhammad. Sebagai seorang rasul, namun juga seorang ahli militer yang hebat dan seorang ekonom yang handal.

Dalam kajian ekonomi khususnya konsumsi Afzalur Rahman lebih menekankan nilai-nilai kualitas kemurnian, standar kehidupan, dan kehidupan sederhana.

Dalam kualitas dan kemurnian kitab suci Al-Qur'an menerangkan dengan jelas berkenan dengan masalah konsumsi ini. Al-Qur'an menganjurkan penggunaan makanan yang baik-baik dan bermanfaat serta melarang pengeluaran yang berlebih-lebihan dan tidak perlu. Ia memerintahkan kaum muslim untuk melakukan dan mempergunakan hanya makanan yang baik-baik dan suci. ${ }^{11}$

Standar kehidupan mengacu pada cara hidup dan tingkat kesenangan yang dianggap perlu dan pendapatan serta pemeliharaan dimana ia siap untuk melakukan pengorbanan yang dihalalkan. Singkat kata, itu berarti sejumlah keperluan dan keinginan minimum, yang dianggap mutlak penting baginya oleh seorang dan yang mendapatkannya ia siap untuk mengorbakan apa saja. ${ }^{12}$

Nabi Muhammad, seperti nabi-nabi pendahuluya, menyukai kehidupan sederhana. Beliau menikmati kesenangan hidup tanpa bermewahmewah dan belebihan. Beliau hidup dalam kesederhanaan dan selalu mengajarkan kaum muslim agar membina suatu kehidupan yang sederhana dan menjauhi pemborosan. ${ }^{13}$

\footnotetext{
${ }^{11}$ Afzalurrahman, op. cit., h.189.

12 Ibid., h. 203.

13 Ibid., h. 209.
} 
Berdasarkan uraian diatas, penulis tergugah untuk mendalami dalam bentuk karya ilmiah yang berjudul "Pemikiran Afzalur Rahman Tentang Konsumsi Dalam Ekonomi Islam”.

2. Rumusan Masalahan

Adapun yang menjadi rumusan masalah dalam makalah ini adalah sebagai berikut:

a. Bagaimana pemikiran Afzalur Rahman tentang konsumsi dalam ekonomi Islam?

3. Tujuan Penelitian

Adapun tujuan penelitian ini adalah :

a. Untuk mengetahui Bagaimana pemikiran Afzalur Rahman tentang konsumsi dalam ekonomi Islam.

Tulisan ini adalah studi kepustakaan (library research) dimana data dan sumber datanya diperoleh dari penela'ahan terhadap literatur-literatur yang sesuai dengan permasalahan.

Dalam memperoleh data, penulis menggunakan data dimana data terbagi tiga yaitu :

1) Bahan Primer

Merupakan literatur yang dikarang oleh Afzalur Rahman, dalam buku Muhammad Sebagai Seorang Pedagang dan Doktrin Ekonomi Islam.

2) Bahan Sekunder

Bahan yang diperoleh dari riset perpustakaan (library reseach) dan dokumen-dokumen yang berhubungan dengan karya ilmiah.

3) Bahan Tersier

Merupakan suatu kumpulan dan kompilasi primer dan sekunder. Contoh bahan tersier adalah bibliografi, katalog kepustakaan, direktori, dan 8 
daftar bacaan. Ensiklopedia dan buku teks adalah contoh bahan yang mencakup baik sumber primer maupun sumber tersier, menyajikan pada satu sisi komentar dan analisis pada sisi lain mencoba menyediakan rangkuman bahan yang tersedia untuk sutu topik. ${ }^{14}$

\section{B. Pembahasan}

1. Pemikiran Afzalur Rahman Tentang Konsumsi Dalam Ekonomi Islam Afzalur Rahman mengemukakan bahwa perintah Islam dalam menentukan konsumsi ditentukan dengan beberapa hal sebagai berikut :

a. Kualitas dan Kemurnian

Al-Qur'anul Karim memberikan kepada kita petunjuk-petunjuk yang sangat jelas dalam hal konsumsi. Ia mendorong penggunaan barang-barang yang baik dan bermanfaat serta melarang adanya pemborosan dan pengeluaran terhadap hal-hal yang tidak penting, juga melarang orang muslim untuk makan dan berpakaian kecuali hanya yang baik. ${ }^{15}$ Berdasarkan ayat yang berbunyi :

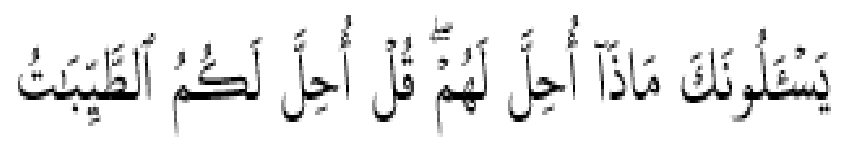

Artinya: "Mereka bertanya kepadamu, makanan apakah yang dihalalkan bagi mereka? Jawablah! Makanan yang dihalalkan bagimu ialah makanan yang baik-baik" (Al-Maidah: 4).16

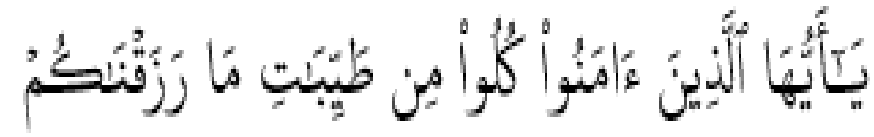

${ }^{14}$ Bambang Sunggono, Metode Penelitian Hukum, (Jakarta: PT. Raja Grafindo Persada, 2006), Cet. Ke 2 h. 114.

15 Afzalur Rahman, Doktrin Ekonomi Islam, (Yogyakarta: PT. Dana Bhakti Wakaf, 1995), Jilid II, h. 18.

${ }^{16}$ Departemen Agama R I, Al-Quran dan Terjemahan, (Semarang: CV. Toha Putra, 1989), h. 158. 
Artinya: "Hai orang-orang beriman! Makanlah diantara rezki yang baik yang kami berikan kepadamu” (Al-Baqarah: 172). ${ }^{17}$

Afzalur Rahman Mengatakan : "Dari ayat-ayat Al-Qur'an yang dikutip diatas, kata yang digunakan untuk barang-barang yang baik adalah berarti segala sesuatu bersifat menyenagkan, manis, baik, enak dipandang mata, harum, dan lezat". ${ }^{18}$

Oleh karena itu, Al-Qur'an menetapkan satu kata terhadap prinsipprinsip umum yang mengatur penggunaan kekayaan dalam suatu masyarakat muslim. Kaum muslimin dianjurkan untuk menggunakan kekayaan mereka (langsung atau tidak langsung) pada hal-hal mereka anggap baik dan menyenangkan bagi mereka. Al-Qur'an tidak menetapkan ketentuan-ketentuan atau aturan-aturan yang tegas tentang apakah barang itu sesuai atau dibolehkan bagi mereka, tapi masyarakat itu diberi keleluasan untuk menentukan tingkat kesucian atas penggunaan barang-barang, khususnya makanan. Hal ini memberi kebebasan dalam memilih barang yang bisa dimakan sesuai dengan yang diinginkan oleh masing-masing penduduk di dunia ini menurut kondisi sosial budaya dan cita rasa mereka masing-masing. ${ }^{19}$

Dengan membolehkan kaum muslim untuk memakan segala sesuatu yang memberikan kelezatan dan kesenangan, Al-Qur'an telah memberikan petunjuk suatu jalan tengah bagi mereka, antara asketisme di satu pihak, yang bersifat anti kesenangan duniawi, dan materialisme di lain pihak, di mana orang-orang menenggelamkan diri mereka dalam kenikmatankenikmatan hidup yang berlebih-lebihan. Dengan kata lain, pantang terhadap segala kenikmatan duniawi adalah sama tidak bersyukurnya

\footnotetext{
${ }^{17}$ Ibid., h. 42.

18 Afzalur Rahman, op. cit., h. 19.

${ }^{19}$ Ibid. 24
} 
dengan menikmatinya secara berlebih-lebihan. Jalan hidup yang terbaik, manurut Al-Qur'an, adalah mengecap kenikmatan-kenikmatan hidup dengan sewajarnya. ${ }^{20}$

Dengan demikian Islam memberi kebebasan individual yang sangat besar dalam masalah konsumsi. Mereka bebas untuk membelanjakan hartanya untuk apa saja yang baik, menyenangkan dan memuaskan keinginan-keinginan mereka, asal tidak malampaui "batas-batas kesucian" ini berarti, kebebasan untuk membelanjakan terbatas pada apa-apa yang baik dan suci saja. Islam tidak memberikan hak pada mereka untuk membelanjakan, atau menghabiskan harta mereka pada hal-hal yang tidak sejalan dengan kesejahteraan sosial. Dengan demikian, semua individu diberi penuh untuk membeli apa-apa yang baik dan suci, asal tidak membahayakan keamanan dan kesejahteraan. Prinsip ini diterangkan dalam ayat berikut ini :

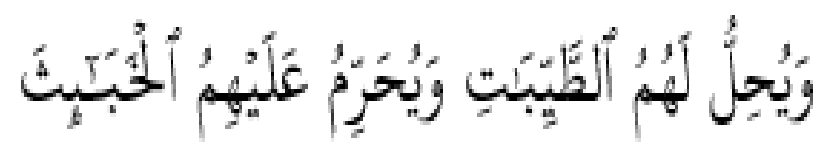

Artinya: “...dan menghalalkan bagi mereka segala yang baik dan mengharamkan bagi mereka segala yang buruk...” (Al-A'raaf: 157). 21

Didalam melakukan konsumsi diperbolehkan penggunaan segala yang baik dan menyenangkan serta melarang penggunaan segala yang tidak baik dan membahayakan. Karena menghormati selera dan kebiasaan individu, kebebasan sepenuhnya diberikan dalam menikmati apa-apa yang dihalalkan, sedangkan konsumsi yang dianggap merugikan kebaikan masyarakat umum, dan merupakan pemborosan nasional, tidak diperbolehkan.

\footnotetext{
${ }^{20}$ Afzalurrahman, op. cit., h. 190.

${ }^{21}$ Departemen Agama R I, op. cit., h. 246.
} 
Afzalur Rahman menegaskan bahwasanya kualitas dan kemurnian dalam konsumsi harus memperhatikan hal-hal sebagai berikut:

1) Jalan Tengah yang Terbaik

Afzalur Rahman mengatakan : “Al-Qur'an telah mengambil satu jalan diantara dua jalan hidup yang ekstrim, yaitu paham materialisme dan paham asketisme. Pada satu sisi, Al-Qur'an melarang pengeluaran belanja yang melampaui batas terutama dalam melapiskan keinginan-keinginan pribadi, sementara disisi lain Islam juga mencela orang yang berpantang diri dari segala kenikmatan yang baik dan suci”, ${ }^{22}$

Orang-orang yang berpantang diri terhadap kesenangan-kesenangan duniawi diperintahkan untuk mengubah sikap mereka terhadap kehidupan. Sebagaimana ayat yang berbunyi :

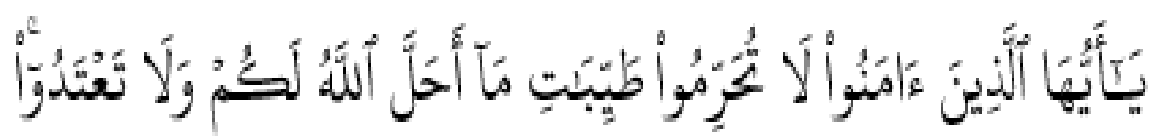

Artinya: "Hai orang-orang yang beriman! Janganlah kamu haramkan apa-apa yang baik yang telah Allah halalkan bagi kamu dan janganlah kamu melampaui batas" (Al-Maa-idah: 87).23

Yusuf Qardhawi juga mengatakan sebagaiman seorang muslim dilarang memperoleh harta dari jalan haram, ia juga dilarang membelanjakan hartanya dalam hal-hal yang diharamkan. Ia juga tidak dibenarkan membelanjakan uang dijalan halal dengan melebihi batas kewajaran karena sikap boros bertentangan dengan paham istikhlaf atau harta milik Allah.

2) Pemborosan Harta

Mengenai pandangan tentang pentingnya kekayaan, Islam memberi banyak penekanan pada pengaturan dan penggunaan kekayaan tersebut.

\footnotetext{
${ }^{22}$ Afzalurrahman, op. cit., h. 191.

${ }^{23}$ Departemen Agama R I, op. cit., h. 176.
} 
Manusia dianjurkan untuk menjaga harta benda mereka dengan hati-hati dan membelanjakannya secara adil dan bijaksana agar keinginan-keinginan yang dihalalkan itu terpenuhi (terpuaskan). Agar pemborosan kekayaan terkontrol, Islam melarang umat untuk memberikan atau mensedekahkan harta benda mereka kepada orang-orang yang belum sempurna berakal dan belum dewasa. ${ }^{24}$ Sebagaimana ayat yang berbunyi :

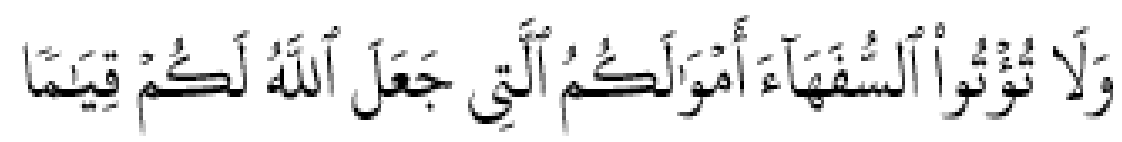

Artinya: "Dan janganlah kamu serahkan kepada orang-orang yang belum sempurna akalnya, harta (mereka yang ada dalam kekuasaanmu) yang dijadikan Allah sebagai pokok kehidupan..." (AnNisaa': 5). ${ }^{25}$

Ini memberikan indikasi bahwa sesungguhnya seluruh kekayaan dimaksudkan untuk dimanfaatkan dan sama sekali tidak boleh dihamburhamburkan atau diserahkan pada orang-orang yang berakal lemah, baik orang yang belum dewasa maupun orang dewasa yang boleh jadi salah dalam memanfaatkan harta itu.

Al-Qur'an menunjukan pada kita cara terbaik untuk membelanjakan harta kita. Pada satu pihak, ia meletakkan tekanan yang bersifat sementara dalam hidup ini. Sementara dilain pihak, ia mengajarkan pada kita bahwa harta kekayaan bukanlah sesuatu yang dianggap yang tidak bernilai serta boleh dibuang begitu saja. Harta benda sarana penunjang dan pendukung bagi manusia di dunia ini.

3) Makanan yang dilarang

Kaum muslim diberi kebebasan penuh dalam bidang konsumsi untuk menikmati apa saja yang sifatnya suci dan menyenangkan bagi mereka, kecuali ada beberapa hal yang membahayakan terhadap masyarakat maupun

\footnotetext{
${ }^{24}$ Afzalur Rahman, op. cit., h. 24.

${ }^{25}$ Departemen Agama R I, op. cit., h. 115.
} 
kesejahteraan individu.26 Afzalur Rahman menegaskan ada beberapa makanan yang dilarang dalam satu komunitas muslim disebut dalam ayat berikut:

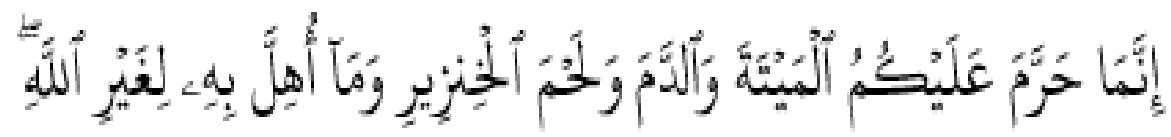

Artinya: "Sesungguhnya Allah hanya mengharamkan bagimu bangkai, darah, daging babi, dan binatang yang ketika disembelih disebut nama selain nama Allah" (Al-Baqarah: 173). ${ }^{27}$

Ada empat hal yang terlarang bagi kaum muslimin, yaitu binatang yang mati dengan sendirinya dan binatang yang mati karena diterkam dengan binatang buas lainnya, darah, daging babi. Dan ayat tersebut juga mengatakan bahwa binatang yang ketika disembelih disebut nama selain Allah, haram dan tidak boleh dimakan. Selain dari keempat jenis makanan tersebut judi dan arak juga diharamkan oleh Al-Qur'an. ${ }^{28}$

\section{4) Karekteristik Konsumsi}

Konsumsi kekayaan dalam Islam mempunyai keunikan-keunikan tersendiri. Pertama, tidak tidak ada perbedaan antara pengeluaran belanja yang bersifat spritual dan duniawi. Di dalam agama lain di dunia, ada suatu garis demarkasi yang jelas antara pengeluaran religius dan pengeluaran yang bersifat non religius atau duniawi.

Ada tindakan-tindakan tertentu yang dapat disebut religius dan spritual, sementara yang lain sebagai non religius atau duniawi. Islam tidak membuat perbedaan seperti itu antara satu jenis pengeluaran (perbuatan) dan yang lainnya. Adalah suatu tindakan yang mulia, memberikan harta pada para janda, anak yatim dan orang miskin. Namun ini sama mulianya dengan

\footnotetext{
${ }^{26}$ Afzalurrahman, op. cit., h. 192.

${ }^{27}$ Departemen Agama R I, op. cit., h. 42.

${ }^{28}$ Afzalur Rahman, op. cit., h. 26.
} 
membelanjakan harta bagi diri sendiri, anak-anak, orang tua, serta kaum kerabat kita.

Kedua, konsumsi tidak dibatasi hanya pada kebutuhan hidup atau kebutuhan efisiensi akan tetapi mencakup kesenangan-kesenangan dan bahkan barang-barang mewah yang dihalalkan. Al-Qur'an dengan segala murah hati memperbolehkan kita untuk mengambil manfaat dari kesenangan, dan berbagai kemewahan hidup. ${ }^{29}$

\section{5) Tempat Perlindungan}

Di dalam Al-Qur'an disebut dengan bangunan-bangunan, istana, rumah kaca, tenda, dan lain-lain, yang dibangun oleh manusia pada masa lalu untuk perlindungan dan kekuatannya. Didirikanmya bangunanbangunan yang sangat besar dan benteng perlindungan yang sangat kokoh. ${ }^{30}$ Sebagaimana ayat yang berbunyi:

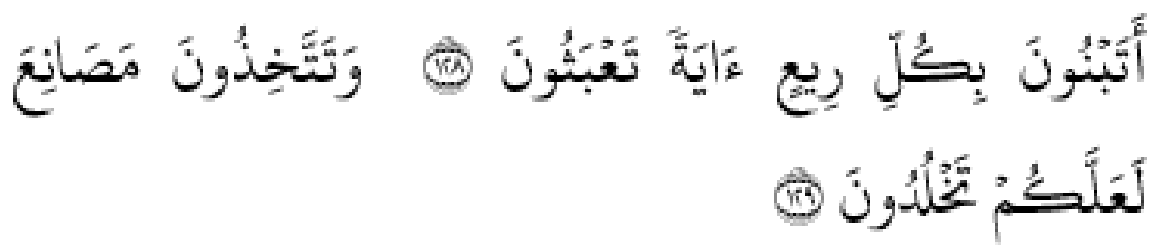

Artinya: "Apakah kamu mendirikan bangunan pada tiap-tiap tanah tinggi? Dan kamu membuat benteng-benteng dengan maksud supaya kamu kekal (di dunia)". (Asy Syuaa'raa: 128-129). ${ }^{31}$

Kata-kata yang dipergunakan disini memberikan indikasi tentang bangunan yang megah yang merupakan suatu benda kebesaran. Bangunanbangunan dan benteng-benteng ini dianggap aman dari serangan-serangan musuh. $^{32}$

6) Kebutuhan-kebutuhan Efisiensi

\footnotetext{
${ }^{29}$ Ibid., h. 193-194.

${ }^{30}$ Afzalur Rahman, op. cit., h. 195-196

${ }^{31}$ Departemen Agama R I, op. cit., h. 582-583.

${ }^{32}$ Afzalurrahman, op. cit., h. 197.
} 
Kebutuhan-kebutuhan yang tidak begitu esensial seperti makanan, pakaian, dan tempat tinggal, tetapi diperlukan untuk meningkatkan kebutuhan efesiensi. Seseorang buruh membutuhkan makanan yang baik, termasuk daging, susu, dan lain-lain, untuk menjaga agar ia tetap sehat, kuat, dan dapat bekerja. Makanan-makanan tersebut adalah kebutuhankebutuhan efisiensi bagi seorang buruh. Jelasnya, apa saja yang dapat menambah efisiensi dan membuat manusia menjadi seorang pekerja yang lebih baik disebut dengan kebutuhan efisiensi. Itu mungkin juga berupa tidur enak diatas sebuah ranjang yang menyenangkan, atau sepasang sepatu yang baik dan enak dipakai. Jika benda-benda itu membuat seseorang merasa lebih bahagia dan menjadikannya bekerja lebih baik, maka bendabenda tersebut dianggap sebagai kebutuhan-kebutuhan efisiensi. Mengkonsumsi buah-buahan secara teratur mungkin juga dapat membuat seseorang menjadi lebih sehat dan lebih efisien dalam bekerja. ${ }^{33}$

\section{b. Standar Kehidupan}

Standar kehidupan mengacu pada cara hidup dan tingkat kesenangan yang dianggap perlu dan pendapatan serta pemeliharaan dimana ia siap untuk melakukan pengorbanan-pengorbanan yang dihalalkan. Berarti sejumlah keperluan dan kesenangan minimum, yang dianggap mutlak baginya oleh seseorang dan yang untuk mendapatkannya ia siap mengorbankan apa saja.

Dalam masalah gradasi standar ekonomi, Islam tidak menuntut persamaan, akan tetapi akan menyangkut pembagian kebutuhan dasar hidup, Islam mempertahankan persamaan serta menerima prinsip hak untuk mepertahankan hidup dari setiap warga negara.

33 Ibid., h. 198-199. 
Islam menegaskan bahwa tidak seorangpun dihilangkan kebutuhan dasar hidupnya dan bahwa tidak seorangpun boleh menghambur-hamburkan kekayaannya dalam kemewahan. Islam menganggap sebagai tanggungjawab negara untuk membagikan kebutuhan-kebutuhan pokok pada warga negaranya serta untuk menjaga perbedaan dalam gradasi-gradasi ekonomi dalam batas-batas kesederhanaan dan kewajaran,

Afzalur Rahman menegaskan didalam standar kehidupan perlu diperhatikan hal-hal sebagai berikut:

\section{1) Kekikiran}

Kekikiran mengandung dua arti, pertama, jika seseorang tidak mengeluarkan hartanya untuk diri dan keluarganya sesuai dengan kemampuannya. Kedua, jika seseorang tidak membelanjakan suatu apapun untuk tujuan-tujuan yang baik dan amal.

Afzalur Rahman mengatakan: "Orang yang menolak untuk mengeluarkan hartanya demi pemuasan keinginannya atau berusaha untuk bersifat kikir dalam pengeluaran mereka, dalam Islam secara umum dianggap sebagai pelaku kejahatan". ${ }^{34}$

Pertama, mereka tidak bersyukur pada Allah dengan tidak mau membelanjakan harta yang Allah anugerahkan pada mereka sendiri untuk diri sendiri, keluarga atau teman-teman mereka. Tindakan mereka mengingkari nikmat itu dilukiskan dalam surat Ali Imran yang berbunyi :

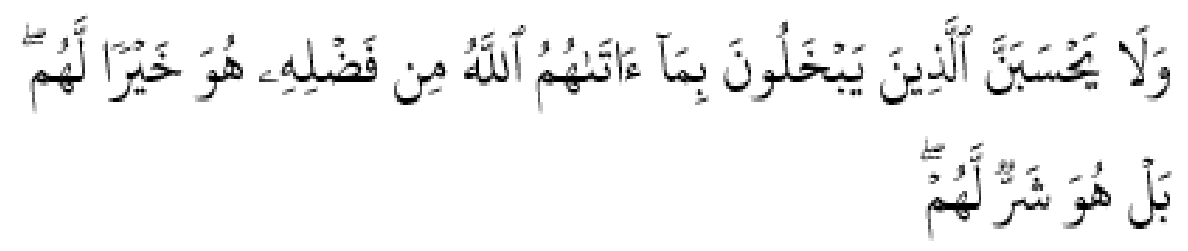

${ }^{34}$ Afzalurrahman, op. cit., h. 203-204. 
Artinya: "Dan janganlah orang-orang yang bakhil dengan harta yang Allah berikan kepada mereka dari karunia-Nya menyangka bahwa kebakhilan itu baik bagi mereka. Sebenarnya kebakhilan itu adalah buruk bagi mereka". (Ali-Imran: 180) ${ }^{35}$

Dengan menyebut harta kekayaan sebagai karunia Allah, orangorang diperingatkan bahwa manfaat harta yang sebenarnya itu terletak dalam penafkahannya dan bukan menumpuknya. Orang-orang yang menumpuk kekayaannya berarti tidak bersyukur. Sebab, mereka tidak memanfaatkannya untuk tujuan diciptakannya harta itu. Disamping itu, dengan menahan harta kekayaan dari komunitas, berarti mereka mereka juga menghilangkan manfaat harta tersebut untuk orang lain. Ini merupakan penyalahgunaan karunia Allah yang dimaksudkan untuk kebaikan semua orang.

2) Pemborosan

Pemborosan mengandung tiga arti. Pertama, membelanjakan harta untuk hal-hal yang diharamkan seperti judi, minuman keras, dan lain-lain apalagi dalam jumlah yang sangat banyak. Kedua, pengeluaran yang berlebih-lebihan untuk barang yang halal, baik didalam maupun diluar batas kemampuan seseorang. Ketiga, pengeluaran untuk tujuan-tujuan amal saleh tetapi dilakukan semata-mata untuk pamer.

Islam juga mencela para pemboros. Kekikiran menahan masyarakat untuk mempergunaan sumber daya dengan baik, sementara pemborosan menghambur-hamburkan harta pada hal-hal yang tidak perlu dan berlebihlebihan. ${ }^{36}$ Sebagaimana ayat yang berbunyi:

\footnotetext{
${ }^{35}$ Departemen Agama R I, op. cit., h. 108.

${ }^{36}$ Departemen Agama R I, op. cit., h. 205-206.
} 


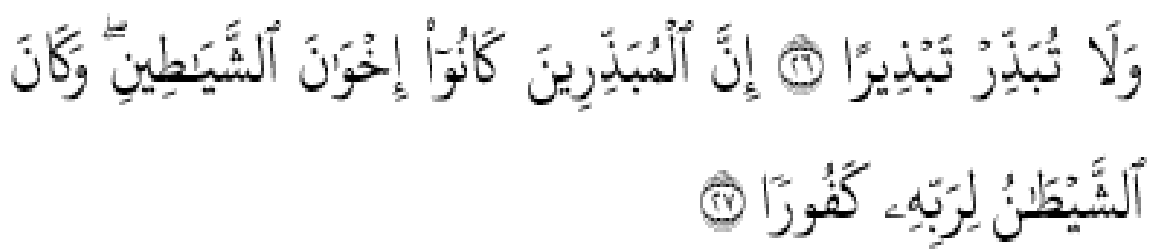

Artinya: "Dan janganlah kamu menghambur-hamburkan (hartamu) secara boros. Sesungguhnya pemboros-pemboros itu adalah saudarasaudara syaitan, dan syaitan itu adalah sangat ingkar kepada Tuhannya". (Al-Israa': 26-27). ${ }^{37}$

Afzalur Rahman menegaskan bahwasanya orang yang menghamburhamburkan hartanya disebut sebagai saudaranya syaitan. Mereka tidak mau bersyukur pada Allah dengan cara tidak menafkahkan segala yang dianugrahkan pada mereka dari karunia-Nya dengan cara yang benar dan halal. Jelasnya, seluruh pengeluaran belanja kita dikondisikan oleh kekayan kita. Tidaklah ada nilainya jika kita menafkahkan harta semata-mata untuk pamer. Berapa banyak keluarga yang hancur akibat pengeluaran belanja yang berlebihan untuk pesta-pesta perkawinan, pemakaman, dan lain-lain. Disamping itu, pemborosan akan merangsang tumbuhnya kemalasan dan memicu munculnya industri-industri yang tidak produktif yang mewah dalam masyarakat. ${ }^{38}$

3) Jalan Tengah yang Baik

Afzalur Rahman mengatakan : "Islam menganjurkan suatu jalan tengah yang baik antara dua jalan hidup yang ekstrim dengan memerintahkan pengeluaran belanja yang wajar tanpa ada mubazir. Hemat, namun tidak kikir". 39

Islam menganjurkan kesederhanaan, baik dalam belanja, maupun menabung. Seseorang tidak boleh terlalu royal sehingga membelanjakan

\footnotetext{
${ }^{37}$ Ibid., h., 428.

${ }^{38}$ Afzalurrahman, op. cit., h. 205-206.

${ }^{39}$ Afzalurrahman, op. cit., h. 206.
} 
seluruh hartanya untuk barang-barang mewah dan kebutuhan-kebutuhan lainnya diluar kemampuannya. Sebaliknya, seseorang tidak boleh bersifat begitu kikir sehingga tidak menafkahkan sesuatupun untuk diri dan keluarganya atau hal-hal yang lainnya yang diperlukan bagi kehidupan sesuai dengan kemampuannya.

Pada hakikatnya ajaran Islam bertujuan menggugah orang agar mengeluarkan harta yang mereka miliki sesuai dengan kemampuan mereka. Pengeluaran mereka tidak boleh melebihi pendapatan yang mereka peroleh. Sebab ini dapat membawa mereka pada pemborosan. Mereka juga dilarang membelanjakan hartanya jauh dibawah kemampauan mereka. Sebab, ini dapat menyeret mereka pada kekikiran. Orang hendaknya bersikap sederhana dalam mengeluarkan harta sehingga pengeluaran tersebut tidak terhambat sirkulasi kekayaan (sebagai dari akibat penimbunan harta) dan tidak pula melemahkan kekuatan ekonomi mereka dan kekuatan ekonomi masyarakat (yang disebabkan oleh pemborosan). ${ }^{40}$ Sebagaimana ayat yang berbunyi:

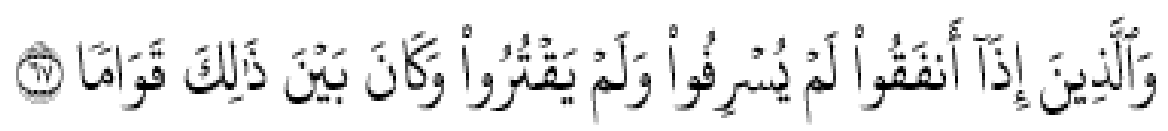

Artinya: "Dan orang-orang yang apabila membelanjakan (harta), mereka tidak berlebihan, dan tidak (pula) kikir, dan adalah (pembelanjaan itu) di tengah-tengah antara yang demikian”. (Alfurqaan: 67$).{ }^{41}$

Inilah aturan yang sangat bijaksana dan bermanfaat dalam soal pengeluaran. Bahkan dalam sedekah, dimana kita berusaha untuk memberikan yang terbaik, tidak dibenarkan untuk bersikap royal, yakni

\footnotetext{
${ }^{40}$ Ibid. h. 215

${ }^{41}$ Departemen Agama R I, op. cit., h. 568.
} 
melakukannya untuk tujuan pamer, untuk membuat orang lain terkesan, atau melakukannya tanpa pikir panjang. ${ }^{42}$

\section{4) Kehidupan Sederhana}

Nabi Muhammad, seperti nabi-nabi pendahulunya, menyukai kehidupan yang sederhana beliau menikmati kesenangan hidup tanpa bermewah-mewah dan berlebihan. Beliau mamakan makanan yang sederhana, memakai pakaian yang sederhana, tinggal dirumah yang sederhana, dan biasa-biasa saja dan memiliki seekor unta atau seekor kuda untuk tunggangan. Beliau hidup dalam kesederhanaan dan selalu menganjurkan kaum muslim agar membina suatu kehidupan yang sederhana dan menjauhkan pemborosan. Walaupun harta nabi melimpah ruah, sepanjang hidupnya beliau hidup berdasarkan kebutuhan-kebutuhan pokoknya saja. Empat orang khalifah sesudah nabi tetap mempertahankan tradisi hidup sederhana beliau itu. ${ }^{43}$

Dengan demikian penghidupan yang sederhana dan bersahaja dalam menikmati kesenangan-kesenangan hidup secara material adalah prinsip yang paling baik yang dianjurkan oleh Islam dalam hal penggunaan kekayaan.

Afzalur Rahman mengatakan : "Prinsip keadilan menentukan cara penggunaan harta, umat Islam diperintahkan supaya terhindar dari sifat bakhil dan harus dapat memelihara dirinya dari bahaya pemborosan harta kekayaan, oleh karena itu mengambil jalan pertengahan diantara kedua jalan ekstrim yaitu antara kebakhilan dan pemborosan harta". ${ }^{44}$

Afzalur Rahman mengemukakan Al-Qur'an telah mengambil jalan tengah diantara dua cara hidup yang ekstrim, yaitu paham materialisme dan

\footnotetext{
${ }^{42}$ Afzalurrahman, op. cit., h. 207.

${ }^{43}$ Afzalurrahman, op. cit., h.. 209.

44 Afzalur Rahman, Doktrin Ekonomi Islam, (Yogyakarta: PT. Dana Bhakti
} Wakaf, 1995), Jilid I, h. 80. 
asketisme. Pada satu sisi Al-Qur'an melarang pengeluaran pembelanjaan yang melampaui batas, terutama dalam melampiaskan keinginan pribadi, sementara disisi lain Islam juga mencela orang yang berpantang dari segala kenikmatan yang baik dan suci. Orang-orang yang berpantang diri terhadap kesenangan duniawi diperintahkan untuk mengubah sikap mereka terhadap kehidupan.

Mannan juga mengatakan bahwa prinsip keadilanlah yang menjadi peraturan utama mengenai konsumsi, dengan mencari rezeki secara halal dari yang dilarang menurut hukum. ${ }^{45}$

Begitu juga Yusuf Al-Qardhawi yang lebih lanjut mengatakan dalam norma dan etika konsumsi seseorang diharuskan menafkahkan harta dalam kebaikan, menjauhi sifat kekikiran dan tindakan mubazir, sikap sederhanalah yang harus dilakukan untuk pemenuhan kebutuhan tersebut. ${ }^{46}$

\section{Kesimpulan}

Dalam sistem ekonomi Islam masalah apapun dalam setiap ativitas ekonomi pada dasarnya lebih memfokuskan pada tujuan dari pada sarana yang maksudnya bahwa setiap apa yang dilakukan dalam konsumsi harus mencari keridhaan Allah SWT, dan terjalinya kemaslahatan umat manusia.

Dalam konsumsi pemikiran Afzalur Rahman lebih memperhatikan beberapa hal yaitu kualitas dan kemurnian, standar kehidupan, dan kehidupan sederhana. Dengan prinsip keadilan untuk menentukan cara penggunaan harta, umat Islam diperintahkan supaya terhindar dari sifat bakhil dan harus dapat memelihara dirinya dari bahaya pemborosan harta

45 M Abdul Mannan, Ekonomi Islam Teori dan Praktek, (Yogyakarta: Dana Bakti Wakaf, 1997), h. 45.

${ }^{46}$ Yusuf Al-Qardhawi, Norma Dan Etika Ekonomi Islam, (Depok: Gema Insani, 2006) Cet Ke-5, h. 67. 
kekayaan, oleh karena itu mengambil jalan pertengahan diantara kedua jalan ekstrim yaitu antara kebakhilan dan pemborosan harta

Afzalur Rahman mengemukakan Al-Qur'an telah mengambil jalan tengah diantara dua cara hidup yang ekstrim, yaitu paham materialisme dan asketisme. Pada satu sisi Al-Qur'an melarang pengeluaran pembelanjaan yang melampaui batas, terutama dalam melampiaskan keinginan pribadi, sementara disisi lain Islam juga mencela orang yang berpantang dari segala kenikmatan yang baik dan suci. Orang-orang yang berpantang diri terhadap kesenangan duniawi diperintahkan untuk mengubah sikap mereka terhadap kehidupan.

\section{Referensi}

Rahman, Afzalur, Doktrin Ekonomi Islam, (Yogyakarta: PT. Dana Bhakti Wakaf, Jilid I, 1995)

Doktrin Ekonomi Islam, (Yogyakarta: PT. Dana Bhakti Wakaf, Jilid II, 1995)

Doktrin Ekonomi Islam, (Yogyakarta: PT. Dana Bhakti Wakaf, Jilid III, 1995)

Muhammad Sebagai Seorang pedagang, Alih bahasa, Dewi

Nurjulianti, (Jakarta: Yayasan Swarna Bhumy, 1997)

Al-Qardhawi, Yusuf, Norma dan Etika Ekonomi Islam, (Jakarta: Gema Insani Press, Cet. Ke-2, 1997)

Departemen Agama R I, Al-Qur'an dan Terjemahan, (Semarang: CV. Toha Putra, 1989)

Mannan, Muhammad Abdul, Ekonomi Islam Teori dan Praktek, (Yogyakarta: Dana Bakti Wakaf, 1997) 
Ph D, Nopirin, Pengantar Ilmu Ekonomi Makro dan Mikro, (Yogyakarta: BPFE, 1994)

Rasyidi, Suherman, Pengantar Teori Ekonomi Pendekatan Kepada Teori Ekonomi Mikro dan Makro, (Jakarta: PT Raja Grafindo Persada, 2000)

Samuelson, Paula dan Wiliam D Nord Haus, Ekonomi, (Jakarta: Erlangga)

Sunggono, Bambang, Metode Penelitian Hukum, (Jakarta: PT. Raja Grafindo Persada, 2006) 